\title{
Using the Edpuzzle tool for teaching programming logic in higher education
}

\section{Utilización de la herramienta Edpuzzle para la enseñanza de la lógica de programación en el nivel superior}

TOLANO-GUTIÉRREZ, Helga Karina†*, AMAVIZCA-VALDEZ, Laura Olivia, PORTELAPEÑÚÑURI, Luis Tadeo and GÁMEZ-WENDLANDT, Julio César

Universidad Tecnológica del Sur de Sonora

ID $1^{\text {st }}$ Author: Helga Karina, Tolano-Gutiérrez / ORC ID: 0000-0002-3848-8115, Researcher ID Thomson: W-20912018, CVU CONACYT ID: 436643

ID $1^{\text {st }}$ Coauthor: Laura Olivia, Amavizca-Valdez / ORC ID: 0000-0003-1614-110x, Researcher ID Thomson: W-21402018, CVU CONACYT ID: 877335

ID $2^{\text {nd }}$ Coauthor: Luis Tadeo, Portela-Peñuñuri / ORC ID: 0000-0002-1597-7047, Researcher ID Thomson: AAG-29682019, CVU CONACYT ID: 761415

ID $3^{\text {rd }}$ Coauthor: Julio César, Gámez-Wendlandt / ORC ID: 0000-0001-9909-688x, Researcher ID Thomson: W-61962018, CVU CONACYT ID: 898833

DOI: $10.35429 / E J R O P .2019 .9 .5 .20 .25$

Received September 22, 2019; Accepted December 15, 2019

\begin{abstract}
This article consists of a quantitative investigation that shows the results of the use of Edpuzzle as a learning tool in a face-to-face class of a programming course offered at the Technological University of Southern Sonora (UTS). The study consisted in the development of an interactive video on the Edpuzzle platform to deliver and evaluate a topic that students sometimes consider difficult to learn. The tool allowed the evaluation of the students who used the learning material developed for the topic. An analysis was made of the resulting information that showed a higher performance, with a difference of 17.14 percentage points, in the group that used the tool. Also, students participating in the experimental group expressed, through a non-formal interview, that the application seemed different to how the classes are conducted at the University, but they considered it very attractive, dynamic and interesting to use in future classes to support other topics.
\end{abstract}

Teaching-learning, Programming, Edpuzzle

\begin{abstract}
Resumen
Este artículo consiste en una investigación cuantitativa que muestra los resultados de la utilización de Edpuzzle como herramienta de apoyo para el desarrollo del aprendizaje en una clase de modalidad presencial, correspondiente a la asignatura metodología de la programación de la carrera de Desarrollo de Software Multiplataforma, en la Universidad Tecnológica del Sur de Sonora (UTS). El estudio consistió en el desarrollo de un video interactivo en la plataforma Edpuzzle para exponer y evaluar un tema que en ocasiones resulta complejo de entender, permitiendo evaluar la comprensión de los estudiantes que utilizaron este material. Se hizo un análisis de la información resultante que mostró un mayor desempeño con una diferencia de 17.14 puntos porcentuales en el grupo que utilizó la herramienta. Los estudiantes participantes en el grupo experimental manifestaron, a través de una entrevista no formal, que la aplicación les pareció diferente a como llevan sus clases en la Universidad, pero la consideraron muy atractiva, dinámica e interesante para llevar en futuras clase como apoyo a los temas que se desarrollan en las diferentes asignaturas.
\end{abstract}

Enseñanza-aprendizaje, Programación, Edpuzzle

Citation: TOLANO-GUTIÉRREZ, Helga Karina, AMAVIZCA-VALDEZ, Laura Olivia, PORTELA-PEÑÚÑURI, Luis Tadeo and GÁMEZ-WENDLANDT, Julio César. Using the Edpuzzle tool for teaching programming logic in higher education. ECORFAN Journal-Republic of Paraguay 2019, 5-9: 20-25

\footnotetext{
* Correspondence to Author (email: ktolano@uts.edu.mx)

$\dagger$ Researcher contributing first author.
} 


\section{Introduction}

Young students seek, require and demand new ways of acquiring knowledge inside and outside the classroom, with personalization and interactivity characteristics, based on current technologies, complementing or changing the traditional way we use to generate learning.

Technology-based learning tools can be a complement to support the face-to-face computer programming courses, some of these artifacts were not designed solely for an approach or environment, but can simply be tested and see that it works in different modalities, therefore they do not limit in that aspect the work of the teacher. An interesting example of these experiences is shown in a study by the University of Alicante in 2017, which raises the Edpuzzle tool as an educational platform in itself, which allows the method of inverted learning to be exploited. But not only such a method, but also seeks to be an effective complement in the transmission of knowledge, this through multimedia content within the class, which is a format of the most used and successful to generate knowledge today. Edpuzzle, allows you to choose any video, add voice memos and questions, as well as monitor student understanding.

\section{Problem Statement}

According to information from the National Center for Educational Statistics of the United States, it is around 2005 when an important decrease in enrollment and an increase in the dropout rate in computer programs began. This has caused a deficit of qualified IT professionals that meets the demand currently in the labor market (Roberts, 2016). And although recently there has been a slight increase in this type of enrollment, the number of students in these programs is far from being what they initially were and meeting current employment demands. Generating experts in the programming discipline requires developing computational thinking, fostering students' logical and mathematical skills. To implement the solution of a problem through the use of a computer it is necessary to establish a series of steps to solve a problem, this set of steps is called an algorithm, which should have as a final feature the possibility of easily transcribing it to a programming language (Zamora, sf).
Teaching-learning programming has been a recurring problem in recent years around the world. Over time, many solutions have been proposed without any of them being really effective. The lack of an in-depth study of the skills that they must acquire is added to the motivation problems of the students, often reducing the courses to a syntactic structure of a programming language (Villalobos, 2009).

The main causes of the difficulty in learning to program computers is that their teaching is based on the process of migrating from natural language to an artificial language such as programming, using mainly application software designed by large corporations that is manifested in concrete activities with these programs. Using a compiler from a specific company forces you to write certain codes in your own way or limits the use of others; In this way, you learn directly to program about language, but without guiding the student towards creativity, problem solving and logical abstract reasoning (Pérez, 2015). These forms of teaching programming often contribute to generating rejection, demotivation and difficulty in achieving learning. Unfortunately, students often experience fear and intimidation regarding introductory programming language courses (Sun, 2018).

Students seek, require and demand new ways of acquiring knowledge in this and other disciplines, inside and outside the classroom, with personalization and interactivity characteristics, based on current technologies, complementing or changing the traditional way we use to generate learning.

The Technological University of the South of Sonora has taught programming for more than 16 years, frequently presenting high rates of disapproval, attrition, demotivation and frustration in students, which is why it becomes a necessity to seek to innovate with other methods of teaching learning. These works can be started with the use and testing of some current teaching tools that could contribute to improving these indicators. Edpuzzle will be used to support the development of learning a topic in face-to-face class, of the programming methodology subject, of a group of the Multiplatform Software Development career, of the Technological University of South Sonora. 
Trying to explore, apply and collect the results of the use of the learning tool, with the objective that the process is interactive and motivating, but at the same time trying to develop the computational logic on which the programming is based, allowing each student go at their own pace on the subject and promote learning autonomy.

\section{Methodology}

This study is of quantitative type and consisted of the use of the Edpuzzle tool to evaluate the learning of a group of students in the topic of flowcharts, of the programming methodology subject of the University's Multiplatform Software Development program Technology of Southern Sonora. A total of 19 students participated in this work, where 5 of them were in the pilot phase. Another 7 young people received a short interactive video to support some reagents of exposed content as support material for the classroom.

The rest, 7 students, were evaluated in a traditional written way through a questionnaire to measure the learning obtained. All of them randomly selected and enrolled in the same school group to take care of equal conditions (such as teacher, schedule, content and previous topics seen in class).

\section{Descriptive sheet of the experimental group:}

The experimental group to carry out the application of the tool consisted of 7 students of the Multiplatform Software Development career, first semester, 3 women and 4 men. All of the same group "A", therefore are on equal terms, as factors such as teacher performance and schedule among others do not affect the results of the experiment since they have the same teacher, schedules, previous topics, etc. Students were randomly chosen using the "random" tool (random.org) and their ages ranged from 17 to 19 years. All of them had to register on the Edpuzzle platform and be evaluated using the tool.

\section{Descriptive sheet of the group without treatment:}

The untreated control group consisted of 7 students of the Multiplatform Software Development career, first semester, 2 women and 5 men.
All of the same group "A", therefore are on equal terms, as factors such as teacher performance and schedule do not affect the experiment since they have the same teacher and materials. Students were randomly chosen using the "random" tool (random.org) and their ages ranged from 17 to 19 years. This group was only given a 50-minute session addressing the issue and subsequently provided with the printed assessment tool, without access to supporting material.

The tool with which the evaluation was developed was Edpuzzle, an interactive video of the topic Data Flow Diagram (DFD) was created, using an existing video of the topic, to which a questionnaire, voice notes and comments were added.

To access the tool you can access the Edpuzzle.com site, you must register and enter the password of the course that is datumle.

Programming Methodology is ready for your students

That was easy! Here is the Class Code you can forward or print for your students. It is they key to connect them to your class.

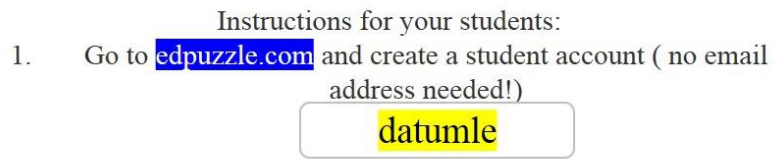

2. Enter the class code when needed and complete the sign up 3. Explore your new class and assignments!

\section{Co Googrle Play}

Figure 1 Entry to course on platform Source: Edpuzzle.com

Evaluation tool (reagents):

1. A flow chart is:

They are a set of symbols that allow communication.

It is the graphic representation of an algorithm. It is a set of steps to solve a problem. It is the symbolic representation of a problem.

Feedback: A data flow diagram is the graphical representation of an algorithm through symbols that relate to each other and indicate that the instructions must be executed to obtain a result. 
2. The characteristics of the flowcharts are: They have a beginning and an end, they are read from top to bottom and from left to right.

They can have several beginnings and are read from left to right. It has a beginning and they are read from right to left.

They have a beginning and an end, they are read from the bottom up and from right to left.

by:

Feedback: A flowchart is characterized

- $\quad$ Have only one starting and ending point per diagram.

They are interpreted from top to bottom (top-botton) and from left to right (leftright).

3. This DFD symbol represents the actions to be executed in a data flow diagram.

Decision.

Data flow lines.

Data entry

Process

Departure

Feedback: The process symbol represents the actions to be executed in a data flow diagram.

4. It is the first step to develop a DFD.

Draw the start symbol and draw a line with vertical flow to join it with the following symbol.

Identify data inputs and outputs.

Assign a title to DFD.

Feedback:

The first thing we have to do when developing a DFD is to identify the data inputs and outputs that we need to solve the problem through this tool.

5. Indicates that it represents each symbol that composes a flowchart.

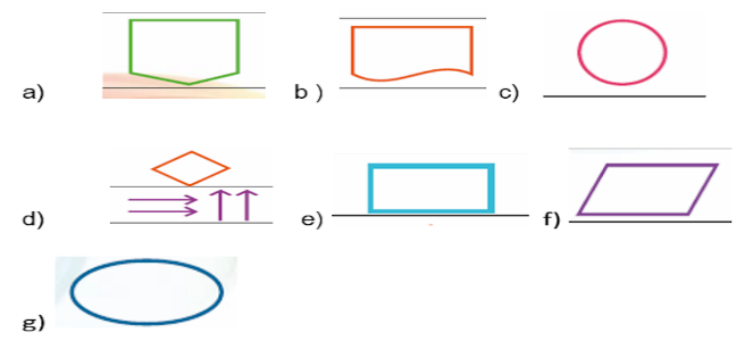

Figure 2 Flowchart Symbols

Source: Own Elaboration

Terminal

Entrance exit

Process

In-page connector

Off-page connector

Print

\section{Results}

The results obtained from the application of this tool were the following:

First, we proceeded to empty the results obtained in the first group, the experimental group, who used Edpuzzle as a support tool for the topic seen in Data Flow Diagrams (DFD). The following information was obtained:

\begin{tabular}{|r|l|r|}
\hline \multicolumn{2}{|c|}{ First name } & $\begin{array}{c}\text { Pts. Obtained (of 5 in } \\
\text { total) }\end{array}$ \\
\hline 1 & $\begin{array}{l}\text { Hernández Grijalva Luis } \\
\text { Manuel }\end{array}$ & 2 \\
\hline 2 & López García Luis Aarón & 4 \\
\hline 3 & Félix Ayala Manuel De Jesús & 3 \\
\hline 4 & Rivas Vega Rosa Elizabeth & 5 \\
\hline 5 & Loera Duarte Noelia Yenedit & 5 \\
\hline 6 & Palafox Cuen Itzel Samantha & 4 \\
\hline 7 & Esparza Peinado Hansel Jesús & 5 \\
\hline & Average & 4 \\
\hline & Mean & 80 \\
\hline
\end{tabular}

Table 1 Results obtained in the experimental group Source: Own Elaboration

Subsequently, the data obtained from the second group were concentrated, which only received a traditional session (presentation by the teacher) and the subject evaluation was applied. 


\begin{tabular}{|c|c|c|}
\hline \multicolumn{3}{|c|}{ Control Group } \\
\hline & First name & Points. obtained \\
\hline 1 & Encinas Simuez Olga Guadalupe & \\
\hline 2 & Enríquez Valencia Ohman Santana & \\
\hline 3 & Estrella Parra Ramón Alberto & \\
\hline 4 & Valdez Gaytán Ariel Armando & \\
\hline 5 & Flores Lumbrera Isabel Alejandra & \\
\hline 6 & Hernández Coronado Jorge Enrique & \\
\hline 7 & Yépiz Sanez Dinorah Guadalupe & \\
\hline & Average & 62.86 \\
\hline & Mean & \\
\hline
\end{tabular}

Table 2 Results of a traditional printed evaluation tool (questionnaire)

Source: Own Elaboration

Finally, an analysis of the information was made, which shows that the results of the evaluation, which are of higher performance in the experimental group that used the interactive video. Specifically there is a difference of 17.14 percentage points, which indicates that the group with treatment had a better learning. Likewise, the average was 4 points in the experimental group and in the group without treatment it was 3 points. The students were interviewed, who said that the tool seemed different to how they take their classes at the University, but they considered it very attractive, dynamic and interesting to take in class to support the subject.

An intervention plan was developed with the objective of carrying out some actions to improve student performance, in current and future programming methodology topics. This according to positive results that were obtained with the interactive multimedia material. These activities consisted of peer counseling (personalization of the advisory activity), complement the face-to-face course with a MOOC (Massive online open course) to support the teaching of programming logic which uses tools similar to Edpuzzle and develop continuous evaluations using multimedia material that allows Edpuzzle.

\section{Conclusions}

A teacher today must be able to adapt to the current needs of students, the use of applications and technologies in education, this due to the positive results obtained from the use of some or many of them in learning.
There is a great variety, however, some have already been subject to research and successful experiences, which allow them to be tested in groups with greater confidence, especially those that use audiovisual content, which are widely accepted, motivating and have had good results among the student population.

The Edpuzzle tool for its multimedia and interactivity characteristics can be considered a good option to teach the basics of programming logic and allow students not to see their contents as boring and demotivating, as well as with important features such as each student can advance to your own pace Further research will be carried out by applying this tool to others of the program and others for complete programming courses. Likewise, in the long term it is intended to generate a successful methodology that allows solving current problems in programming teaching.

\section{References}

Pueo, B., Jiménez, J. \& Penichet, A. (2017). Aplicación de la herramienta Edpuzzle en entornos de aprendizaje individuales dentro del aula. Universidad de Alicante.

Pérez, H. O. (2014). Herramientas informáticas para el desarrollo del pensamiento computacional. Quito, Ecuador: Universidad Central de Ecuador.

Pérez, H. O. (2015). Entornos de programación no mediados simbólicamente para el desarrollo del pensamiento computacional. Una experiencia en la formación de profesores de Informática de la Universidad Central del Ecuador. RED-Revista de Educación a Distancia, 46-68.

Roberts, E. A. (2016). History of Capacity Challenges in Computer Science. Recuperado de

https://cs.stanford.edu/people/eroberts/CSCapa city.pdf

Sun, L., Frederick, C.M., Liron, C., Ding, L., y Gu, L. (2018). Workshop 4: Get Rid of Your Students' Fear and Intimidation of Learning a Programming Language By Applying Second Language Acquisition in a Blended Learning Environment. The 9th First Year Engineering Experience (FYEE) Conference, Daytona Beach, FL. 
Villalobos, J. A. (2009). Cupi-2 Una Solución al problema de aprender/enseñar a programar. Bogotá, Colombia: Universidad de los Andes.

Zamora, M.A. (s.f), Todos deberíamos saber crear algoritmos. Universidad Autonóma de Hidalgo. Recuperado de https://www.uaeh.edu.mx 